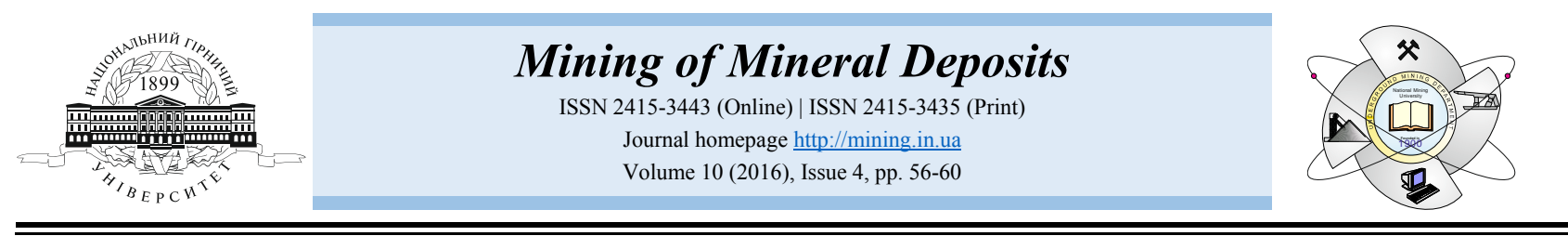

UDC 622.272

\title{
IMPACT OF NEW TECHNOLOGIES IN HARD ROCK UNDERGROUND MINING TAKING INTO ACCOUNT OPERATIONAL EFFICIENCIES AND PRODUCTION RATES
}

\author{
V. Dhookie ${ }^{1 *}$ \\ ${ }^{1}$ Business Development, IBM, Johannesburg, Republic of South Africa \\ *Corresponding author: e-mailvdhookie@yahoo.com, tel.+270824966586
}

\section{ВПЛИВ НОВІТНІХ ТЕХНОЛОГІЙ ПРИ ПІДЗЕМНІЙ РОЗРОБЦІ РОДОВИЩ З УРАХУВАННЯМ ЕФЕКТИВНОСТІ ТА ПРОДУКТИВНОСТІ ЇХ ЕКСПЛУАТАЦЇ̈}

\author{
В. Дгооке $\epsilon^{1 *}$ \\ ${ }^{I}$ Відділ розвитку, IВМ, Йоганнесбург, Південно-Африканська Республіка \\ *Bidповідальний aвтор: e-mailvdhookie@yahoo.com, тел +27824966586
}

\begin{abstract}
Purpose: The purpose of this paper is to discuss the impact that new technology will have and a few of the key areas to be addressed that will ensure a successful and sustained adoption of new technologies within mining organizations.

Methods: Analysis and the practical experience of implementing technology to enable organization wide transformations across multiple industries.

Findings: Five key areas will need to be taken into account in driving to improved levels of production rates, greater operational efficiencies and higher health and safety levels namely technology, mechanization, people, equipment and economic sustainability.

Originality: Ensuring that all five areas are addressed holistically and no one area in isolation will result in improved production levels and efficiencies and ultimately the achievement of autonomous mining.

Practical implications. There will have to be a significant organisational culture transformation within mining organisations and the ability to foster a culture of learning is going to be critical to the successful adoption of new technology in mining and the subsequent improvements in operational efficiencies and production rates that will result.
\end{abstract}

Keywords: digital, autonomous, mechanization, sustainability, technology, ecosystem

\section{INTRODUCTION}

Mining organisations have constantly attempted to increase operational efficiencies, production and safety levels and the attempt to increasing anyone or all three of these factors have traditionally come at a significant cost. This cost combined with low commodity prices has made mining profitably extremely challenging.

Research conducted has indicated that mining operations are as much as 28 percent less productive today than a decade ago (Lala, Moyo, Rehbach, \& Sellschop, 2015).

The objective of this paper will be to discuss the impact that the introduction of new technologies will have within mining organisations that will ultimately achieve the improved levels of production rates, greater operational efficiencies and higher Health and Safety levels required for sustained profitability and stakeholder value.

In assessing the impact that new technology will have on mining organisations five key areas were taken into account namely, technology, mechanization, people, equipment and economic sustainability. All of which form the core to determining how new technology will impact mining organisations' and fundamentally transform the industry.

\section{THE MAIN PART OF THE ARTICLE}

In driving toward greater operational efficiencies, higher production rates and health and safety levels the following key areas were assessed in order to determine the level of impact that new technology has and will have on mining organisations.

\subsection{Technology}

While there has been constant advancement in technology developments within the mining industry over the years, in the authors opinion the next evolution of technology in the form of the internet of things will see a 
significant step change resulting in a complete overhaul of how mining operations are currently conducted today.

The author believes it will move beyond mere mechanization and truly blur the boundaries of where the physical world meets the digital world thus enabling autonomous mining. It will also enable the convergence of operational technology (OT) and information technology (IT) which in turn will result in mines being able to track ore along the entire value chain, knowing not only what grade of ore will be required to be processed but also when it will arrive at the plant.

The benefits that technology will enable (Examining..., 2016):

1. Predictive Maintenance. Technology enables the ability to detect wear on key pieces of equipment and then through the analysis of data be able to predict when repairs or maintenance needs to take place and thereby avoid extended periods of downtime or failures. This could then lead to the ability to automatically schedule maintenance and repairs and shift tasks to other equipment during its downtime. Actively maintained equipment not only leads to greater productivity but also safety.

2. Efficiency. Improvements in efficiency can be realized by integrating machines and connected devices, for example, giant trucks being able to haul ore autonomously and automatically detect when another vehicle or thing is close to it thus maximizing production and safety. Also by ensuring equipment availability or reducing downtime as previously mentioned can greatly enhance the efficiency of mine operations.

3. Revolutionize Safety. Mining a dangerous profession by its very nature and safety concerns are a high priority. Mining operations will be able to track people and equipment real time as well as monitor their health. Mining organisations will be able to continuously improve its safety by analyzing hazards, incidents, near misses and safety observations.

4. Decision Making. Technology will be an enabler to intelligent decision making in the mining sector and will overall improve how traditional processes and tasks are done. The ability for planners to track the movements of material, as well as accessing all production information.

5. Seamless Automation. Integrating the OT and IT systems will provide the ability to optimize the mine's layout, day-to-day operations, vehicle paths, maintenance schedules etc., thus allowing for the orchestration of all mining operations to ensure the highest levels of efficiency.

6. Energy and Cost Benefits. Utilizing technology will allow for lower expenditures of energy to develop and maintain a site. On-demand Ventilation Systems provide much healthier environments for workers and have automatic technology that can read the amount of contamination in the air and adjust ventilation accordingly. These ventilation systems also allow controllers and monitors to adjust the ventilation manually from a remote control center.

\subsection{Technology}

If one is to look at the South African soft-rock and in particular the underground coal mining sector the adoption of mechanization has occurred during the 1970s - 1990s and now there remains very few drill and blast sections within South Africa (Vogt \& Hattingh, 2016).
On the other hand hard rock South African mining started mechanization in the first quarter of 2014 but the adoption of mechanization has not been as quick as one would have thought. A few of the reasons for this low rate of adoption are the low stoping heights, low ore grades and steep dips. Also to be taken into account with regards to technology adoption is the model of technology implementation in factories (Chew, Leonard-Barton, \& Bohn, 1991) as per Figure 1 below, which depicts a worsening of the performance upon the introduction of new technology and then an improvement to the old state before exceeding levels of performance. The key aspect to take into account while this transition is taking place is cost which often stops initiatives and in so doing mechanization (Vogt \& Hattingh, 2016).

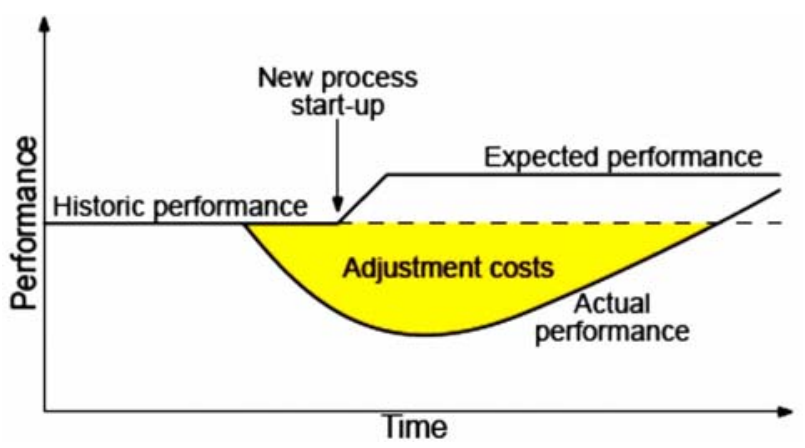

Figure 1. Murphy's Curve. While the details of the curve change, the shape is remarkably consistent (Chew, Leonard-Barton, \& Bohn, 1991)

In order to reduce the costs and time taken to increase performance, mines will have to transform to a learning organisation and instill a culture of learning throughout the organisation (Vogt \& Hattingh, 2016).

The benefits that mechanization will enable are as follows (Fourie, Valicek, Krafft, \& Sevenoaks, 2014):

- reducing staff in the high-risk zone of stopes will lead to safer operations;

- by utilizing remotely operated machines the separation of machines and personnel can be achieved;

- having dedicated teams on development and stoping will result in focused mining of primary development and production stoping;

- primary development ahead of the stoping activity will enable:

a) enables the geology to be better understood in advance;

b) by installing tipping points ahead of stoping provides the ability to immediately create 'stoping reserves', and in so doing providing greater flexibility and less production risk;

- as one is able to recover revenue from on-reef development lower capital is required;

- improved resource sharing and scheduling is achieved as layout allows flexibility between stope sections;

- rapid response to market pressures is enabled through the creation of a flexible mining layout;

- higher head feed grades is directly related to low stoping widths;

- higher square meters mined per employee can be achieved through highproductivity stopes. 


\subsection{People}

The growing trend of mechanization within the mining industry will result in different skills sets being required to drive mining operations going forward. Mining organisations apart from the culture change that will be required will need to start catering for these skills sets in order to fully leverage the new technologies (Fourie, Valicek, Krafft, \& Sevenoaks, 2014):

- safety would be a key concern for operators;

- they will need to be goal-orientated;

- flexibility and adaptability are crucial;

- the ability to think and act strategically;

- the ability to succinctly communicate with others;

- the ability to work in a team and to collaborate strongly focused on teamwork and collaboration;

- understanding software and its applications;

- understand both IT and OT systems and how they interact;

- capable of performing maintenance on equipment.

\subsection{Equipment}

As technology advances occurred there have been numerous new developments in the mining equipment industry. For the purposes of this paper a comparison between low profile equipment and extra/ultra low profile equipment will be made to indicate the improvement in production levels. The low profile equipment is able to achieve $2400 \mathrm{~m}^{2}$ of average monthly production per crew while the extra/ultra profile equipment is able to achieve $>4000 \mathrm{~m}^{2}$ of average monthly production per crew (Fourie, Valicek, Krafft, \& Sevenoaks, 2014). This comparison clearly indicates that higher production levels and greater efficiencies can be achieved within the mining industry using mechanized equipment.

\subsection{Economic sustainability}

Economic sustainability can be defined as "Economic systems support sustainable social and environmental outcomes, where economics is the process through which humans create social and environmental outcomes" (Zadek \& Tuppen, 2000). The author's understanding of the term economic sustainability is that all three pillars environmental, social and economic is taken into account from a continual performance perspective that ensures the organisation stays in business.

The adoption of new technology within mining organisations will impact all three pillars of economic sustainability and pose the following challenges:

1. Environmental - the impact to the environment could be a double edged sword as on one hand the ventilation and electricity required through mechanization could be significantly reduced as use could be made of on demand ventilation and electricity however emissions from equipment, as well as new mining methods that may be adopted may be detrimental to the environment. There are four key measures for this pillar namely (Doane \& MacGillivray, 2001):

- the amount of minerals and waste extracted from the earth;

- the amount of substances produced by people;

- physically harming the environment;

- the broader human race is taken into account and not just locals.
2. Social-there will be less need for labourers' as more and more tasks are automated. This will have a significant impact on the surrounding communities should beneficiation not be enforced. Should beneficiation be pursued this could result in roads, clinics, hospitals, water and electricity being provided to the surrounding communities. There are two key measures for this pillar namely (Doane \& MacGillivray, 2001):

- organisations discuss matters with stakeholders and ensure accountability, thereby understanding the needs and values of stakeholders;

- ensuring that the social, economic and environmental impacts understood and defined by the stakeholders.

3. Economic - the ore-grade, electricity availability, commodity prices and cost of technology could make it unprofitable to mine and thereby reduce economic sustainability. However, with increased production rates and greater operational efficiencies due to the adoption of new technology economic sustainability could be significantly increased. There are four key measures for this pillar namely (Doane \& MacGillivray, 2001):

- how well the organisation is doing financially?

- how intangible assets are managed by the organisation?

- how the broader economy is impacted?

- how social and environmental impacts are managed and influenced by the organisation?

4. Technical - the issue will not necessarily lie with the technology that is to be implemented but in the shift in skillsets and organisational culture that will be required. Following are a number of areas that would need to be considered for the successful adoption of new technology within a mining organisation (Scott, 1998):

- a thorough risk assessment should be conducted with appropriate risk mitigation/minimization strategies in place;

- the technology has to be reliable and work consistently;

- identify and utilize a champion/s within the organisation who will drive and promote the technology;

- the innovation should not make any component of the upstream or downstream processes more complicated or negatively affect performance in any way;

- adequate training should be provided to enable smooth operations of the new technology both from an operational and maintenance/support perspective;

- the impact to production should be kept to a minimum when incorporating the new technology;

- thorough change management needs to be conduct at all levels of the organisation to alleviate any fear or suspicion there may be with regards the new technology;

- trade union resistance will need to be addressed and appropriate measures would need to be implemented based on the impact of the new technology to the labour force.

\section{CONCLUSIONS}

In order for the mining industry to survive and then thrive there has to be significant improvements in efficiencies and production rates. What is evident is that significant improvements will not be realised from organic improvements but through step changes in the adoption of technology. 
The adoption of technology cannot happen in isolation and so the impact that the technology will have on the ecosystem and in particular the way in which work in mining is going to change, as well as the associated skills sets that will be required to conduct the new way of working will need to be taken into account.

There will have to be a significant organisational culture change within mining organisations and the ability to foster a culture of learning is going to be critical to the successful adoption of new technology in mining and the subsequent improvements in operational efficiencies and production rates that will result.

In order to facilitate the adoption of new technology within South African mines the author recommends that mining organisations define their digital transformation strategy which effectively will comprise of catering for the key areas that were considered in understanding the impact of new technology and how to develop and address each of these areas:

1. People-from its current state mining organisations will need to define a change management program to ensure that employees at all levels are made aware of what the new technology is and how it will impact their jobs. Cultivating a learning organisation and developing a centre of excellence within the organisation to not only drive the adoption of the new technology but to provide the constant enablement and innovation of new technologies. This will be a critical function within the organisation going forward.

2. Technology-defining an integrated technology roadmap from both an Operational and Informational technology perspective and what will be required to ultimately achieve autonomous mining will need to be assessed.

3. Equipment - determining which equipment to use that will not only fit the organisation from a cost but also from a predictive maintenance and autonomous mining perspective will need to be assessed.

4. Mechanization - the technology and equipment decision will form the foundation of this decision as well as the organisations level of mechanization requirements and drive to autonomous mining.

5. Economic sustainability - the organisations strategic direction on its business model and whether it would remain focused on only its core business would determine the level of beneficiation attained. The level of beneficiation will determine its impact on social, environmental and economic sustainability.

\section{ACKNOWLEDGEMENTS}

The paper did not originate under any project and no funding was raised.

\section{REFERENCES}

Chew, W.B., Leonard-Barton, D., \& Bohn, R.E. (1991). Beating Murphy's Law. Cambridge: MIT Sloan Management Review.

Doane, D., \& MacGillivray, A. (2001). Economic Sustainability - the Business of Staying in Business. London: New Economic Foundation.

Examining the Internet of Things and its impact on the mining industry in 2016. (2016). Mining Global.

Fourie, F., Valicek, P., Krafft, G., \& Sevenoaks, J. (2014). Narrow Reef Mechanized Mining Layout at Anglo American Platinum. In 6th International Platinum Conference "Platinum-Metal for the Future" (pp. 261-279). Johannesburg: The Southern African Institute of Mining and Metallurgy.

Lala, A., Moyo, M., Rehbach, S., \& Sellschop, R. (2015). Productivity in Mining Operations: Reversing the Downward Trend. New York: Mckinsey \& Company.

Scott, A. (1998). Implementing and Managing New Technologies in Mining. Mount Isa: Australasian Institute of Mining and Metallurgy.

Vogt, D., \& Hattingh, T. (2016). The Importance of People in the Process of Converting a Narrow Tabular Hard-Rock Mine to Mechanization. Journal of the Southern African Institute of Mining and Metallurgy, 116(3), 265-274. https://doi.org/10.17159/2411-9717/2016/v116n3a8

Zadek, S., \& Tuppen, C. (2000). Adding Values - the Economics of Sustainable Business. London: Britisch Telecom Occasional Papers.

\section{ABSTRACT (IN UKRAINIAN)}

Мета. Метою даної статті є аналіз впливу, який буде чинити нова технологія, а також деякі з розглянутих ключових областей, які забезпечують успішне та стабільне впровадження новітніх технологій на гірничодобувних підприємствах.

Методика. Аналіз і практичний досвід технологічних впроваджень для забезпечення значного перетворення підприємства в різних галузях промисловості.

Результати. Встановлено, що для досягнення поліпшення рівня темпів виробництва, підвищення експлуатаційної ефективності й більш високих рівнів охорони здоров'я та безпеки, необхідно враховувати п'ять ключових факторів, а саме: технологію, механізацію, людей, обладнання та економічну стійкість.

Наукова новизна. Новизна роботи забезпечується тим, що всі п'ять факторів розглядаються як єдине ціле i жоден з них окремо не призводить до підвищення рівня виробництва та ефективності, й у кінцевому підсумку досягнення автономного видобутку.

Практична значимість. Повинно бути значне перетворення корпоративної культури на гірничодобувних підприємствах, також повинна бути можливість сприяння формуванню культури навчання, що буде мати вирішальне значення для успішного впровадження нових технологій у гірничодобувній промисловості та в результаті - подальшого поліпшення експлуатаційної ефективності й темпів виробництва.

Ключові слова: цүифровий, автономний, механізація, стійкість, технологія, екосистема 


\section{ABSTRACT (IN RUSSIAN)}

Цель. Целью данной статьи является анализ воздействия, которое будет оказывать новая технология, а также некоторые из рассматриваемых ключевых областей, обеспечивающих успешное и стабильное внедрение новейших технологий на горнодобывающих предприятиях.

Методика. Анализ и практический опыт технологических внедрений для обеспечения обширного преобразования предприятия в различных отраслях промышленности.

Результаты. Установлено, что для достижения улучшения уровня темпов производства, повышения эксплуатационной эффективности и более высоких уровней охраны здоровья и безопасности, необходимо учитывать пять ключевых факторов, а именно: технологию, механизацию, людей, оборудование и экономическую устойчивость.

Научная новизна. Новизна работы обеспечивается тем, что все пять факторов рассматриваются как единое целое и ни один из них в отдельности не приводит к повышению уровня производства и эффективности, и в конечном итоге - достижению автономной добычи.

Практическая значимость. Должно быть значительное преобразование корпоративной культуры на горнодобывающих предприятиях, также должна быть возможность содействия формированию культуры обучения, что будет иметь решающее значение для успешного внедрения новых технологий в горнодобывающей промышленности и в результате - последующего улучшения эксплуатационной эффективности и темпов производства.

Ключевые слова: иифровой, автономный, механизация, устойчивость, технология, экосистема

\section{ARTICLE INFO}

Received: 17 October 2016

Accepted: 16 November 2016

Available online: 30 December 2016

\section{ABOUT AUTHORS}

Dhookie Vickesh, Masters - Mining Engineering, Business Development, Executive - Analytics, IBM, 90 Grayston Drive, Sandton, 2196, Johannesburg, Republic of South Africa. E-mail: vdhookie@yahoo.com 